\title{
Trans Padang Bus Stop Design at UNP Campus Area Using Iconic and Local Wisdom Concept
}

\section{Rancangan Halte Bus Trans Padang pada Kawasan Kampus UNP dengan Konsep Ikonik dan Kearifan Lokal}

\author{
Risma Apdeni ${ }^{1 *}$, Fitra Rifwan ${ }^{1}$
}

\begin{abstract}
In 2015, the number of Trans Padang bus passengers has reached 164,344 people in a year and is predicted will increase every year. Problems arise when the increase of customer numbers is not yet followed by the improvement of facilities and infrastructures, including the bus stop. This research aims to gain a new design of Trans Padang bus stop at UNP campus by using iconic and local wisdom concept. Existing bus stop has an area of $8.8 \mathrm{~m} 2$ and the maximum number of passenger in nonpeak hour is 22 people. The analysis results showed that the ideal area of the bus stop is $11 \mathrm{~m} 2$. It means that the area of existing bus stop must be enlarged to suit the needs of the passengers. Iconic and local wisdom concept of design is appropriate to obtain a bus stop design that will increase the service to the passengers and introduce the local identity of the bus stop location.
\end{abstract}

Keywords

bus stop, trans padang bus, iconic concept

\begin{abstract}
Abstrak
Pada tahun 2015 pengguna Bus Trans Padang telah mencapai 164.344 orang per tahun dan diprediksi akan terus meningkat. Pertumbuhan jumlah penumpang ini belum diiringi dengan penambahan dan perbaikan sarana dan prasarana halte bus. Penelitian ini berupaya mendapatkan rancangan halte bus Trans Padang pada kawasan kampus Universitas Negeri Padang dengan konsep ikonik dan kearifan lokal. Halte eksisting memiliki luas $8,8 \mathrm{~m} 2$ dan jumlah pengguna maksimum pada jam non sibuk adalah 22 orang. Hasil analisis menunjukkan luas halte ideal adalah $11 \mathrm{~m} 2$, sehingga luasan halte eksisting harus diperbesar. Konsep ikonik dan kearifan lokal dinilai cocok untuk menghasilkan rancangan halte bus Trans Padang yang dapat meningkatkan pelayanan terhadap pengguna sekaligus mengenalkan identitas daerah tempat bus Trans Padang tersebut beroperasi.
\end{abstract}

\section{Kata Kunci}

halte bus, bus trans padang, konsep ikonik

${ }^{1}$ Jurusan Teknik Sipil, Universitas Negeri Padang

Fakultas Teknik, Kampus UNP Air Tawar, Jl. Prof. Dr. Hamka, Padang

*risma.apdeni@ft.unp.ac.id

Submitted : July 27, 2019. Accepted : August 23, 2019. Published : September 01, 2019. 


\section{PENDAHULUAN}

Sebagai salah satu sistem transportasi publik, pelayanan Trans Padang dengan prasarana yang tersedia saat ini dinilai belum memuaskan, terutama dalam hal fasilitas halte. Berdasarkan hasil observasi awal, dari 42 unit halte permanen bus Trans Padang yang ada, umumnya bangunan halte masih belum memenuhi standar kelayakan halte sehingga membuat pengguna tidak aman dan nyaman dalam menggunakannya. Perbaikan rancangan fasilitas halte bus Trans Padang harus ditinjau dari segi dimensi, estetika, bahan material serta keamanan dan kenyamanan. Penambahan perbaikan fasilitas bisa juga dilakukan dengan pengadaan tempat duduk, kanopi, ramp, dinding, lantai, warna halte, tata letak fasilitas, kebutuhan papan informasi dan iklan, penambahan alat penerangan (lampu), dan penambahan tempat pembuangan sampah [1].

Fasilitas yang ada di halte eksisting saat ini masih jauh dari memadai sehingga belum bisa mengakomodir kebutuhan pengguna, baik untuk saat ini maupun di masa yang akan datang. Melalui observasi lapangan yang dilakukan pada halte bus Trans Padang di depan kampus Universitas Negeri Padang, dapat dinyatakan bahwa halte belum mampu menampung pengguna bus Trans Padang, terutama pada jam-jam sibuk. Satu halte lain yang berada di seberang kampus juga belum memenuhi standar.

Sebenarnya, selain sebagai bagian dari infrastruktur transportasi publik, halte bus Trans Padang juga dapat dijadikan alat promosi Kota Padang dalam memperkenalkan budayanya. Halte bisa didesain dengan mengusung karakter lokal yang mewakili budaya Kota Padang sebagai salah satu tujuan wisata di Indonesia. Penelitian ini mencoba memberikan solusi dalam bentuk model rancangan halte bus Trans Padang yang sesuai dengan standar yang ada serta memiliki konsep desain yang membawa karakter lokal.

Konsep desain merupakan panduan dalam semua keputusan desain. Desain bangunan secara keseluruhan akan berpengaruh terhadap awal pemilihan konsep itu sendiri. Merancang konsep bangunan terkait dengan arsitektur yang akan ditampilkan. Menurut Broadbent, dalam arsitektur ada beberapa konsep perancangan yang menjadi dasar awal eksplorasi bentuk produk arsitektur, yaitu: pragmatik, ikonik, analogik, dan kanonik [2]. Konsep ini bisa diberlakukan untuk mendesain infrastruktur transportasi, termasuk halte bus.

A. Ibeas et. al. [3] menyatakan bahwa keseimbangan antara halte dan jumlah penumpang tergantung kepada rute dan frekuensi perjalanan moda transportasi. Merancang halte sebagai infrastruktur transportasi tidak terlepas dari jumlah pengguna bus yang berhenti di halte tersebut dan lokasi keberadaannya terhadap jalan. Pada perencanaan halte (bus stop), pertimbangan kapasitas dan aksesibilitas seharusnya menjadi latar depan. Artinya layout jalur bus, tempat perhentian bus, infrastruktur pedestrian, desain kerb, area peron bus, dan sebagainya, tidak hanya ditentukan oleh pertimbangan desain arsitektur dan perkotaan semata [4]. Kapasitas dan kemudahan adalah hal yang utama sekali sebelum eksterior dan interior pada rancangan halte.

Berbagai macam rancangan halte dengan eksterior yang menarik dapat memberikan kenyamanan bagi penumpang. Rancangan halte yang terkait dengan daya tampungnya mengacu kepada Pedoman Teknis Perekayasaan Tempat Perhentian Kendaraan Penumpang Umum [5]. Terkait daya tampung, kapasitas minimum adalah 20 orang per halte pada kondisi biasa, di mana penumpang dapat menunggu dengan nyaman, seperti yang terlihat pada Gambar 1 berikut ini. 


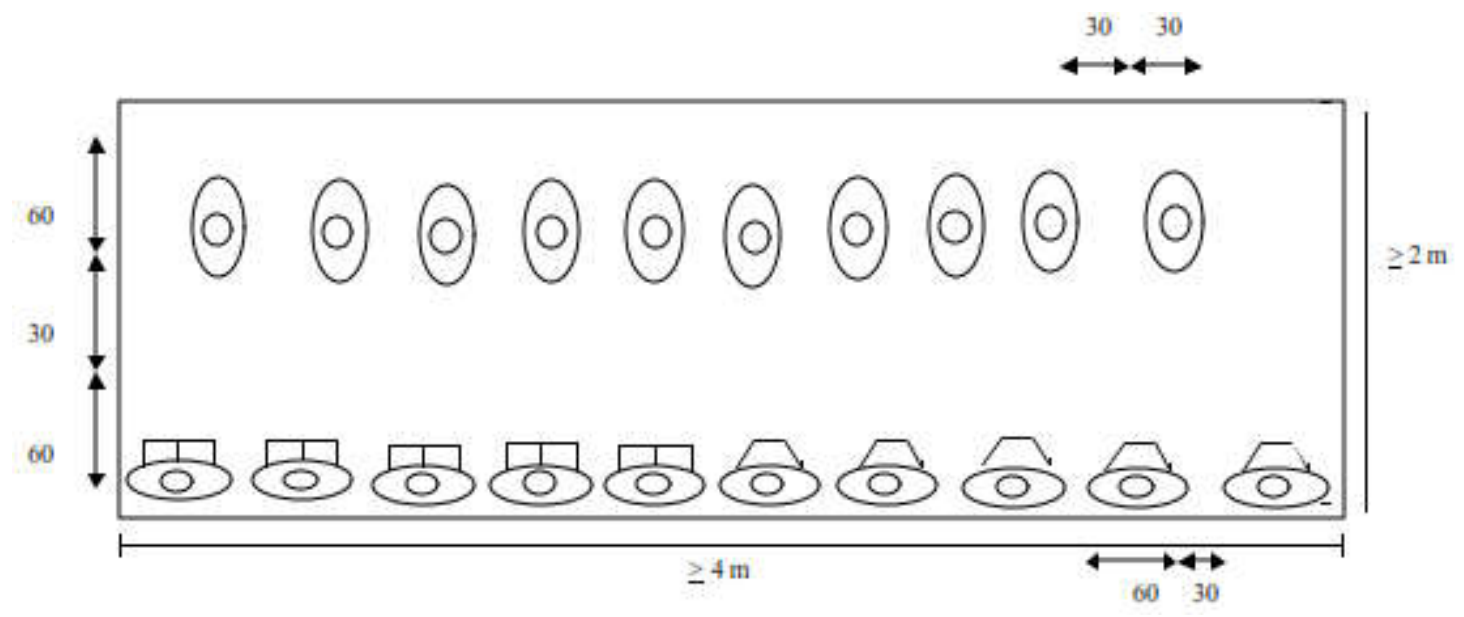

Keterangan Gambar 1:

Gambar 1. Pedoman Rancangan Daya Tampung Halte [5]

1. Kapasitas lindungan (10 berdiri, 10 duduk)

2. Ruang gerak per penumpang di tempat henti $90 \mathrm{~cm} \times 60 \mathrm{~cm}$

3. Jarak bebas antara penumpang:
a. Dalam kota $30 \mathrm{~cm}$
b. Antarkota $60 \mathrm{~cm}$

4. Ukuran tempat henti per kendaraan, panjang $12 \mathrm{~m}$ dan lebar $2,5 \mathrm{~m}$

5. Ukuran lindungan minimum $4,00 \mathrm{~m} \times 2,00 \mathrm{~m}$

Berdasarkan pedoman yang sama dapat ditentukan juga tampak atas, belakang dan samping halte Tipe 1 yang bisa dilihat pada Gambar 2 .
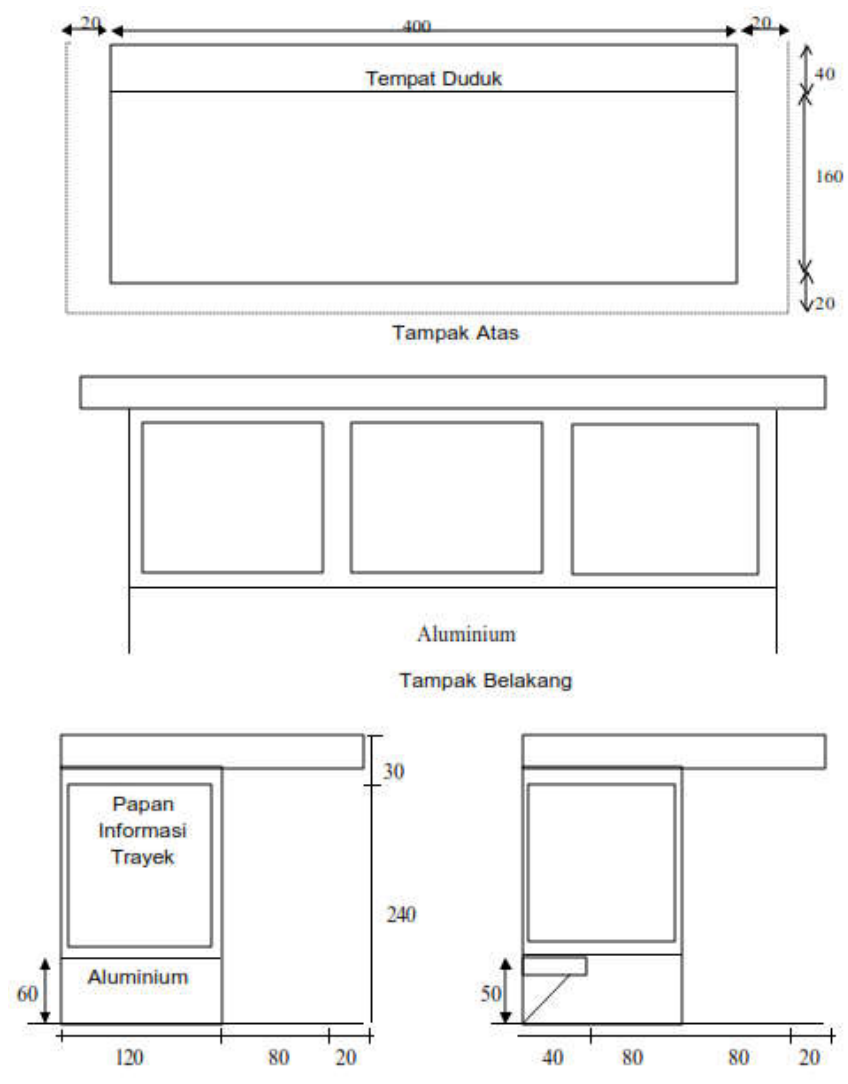

Tampak Samping

Gambar 2. Tampak Atas, Belakang dan Samping Halte Tipe 1 [5] 
Keterangan Gambar 2:

1. Bahan bangunan disesuaikan dengan kondisi setempat.

2. Ukuran minimum dengan luas efektif halte adalah: panjang $=>4 \mathrm{~m}$, lebar $=>2 \mathrm{~m}$

Adapun untuk halte Tipe 2 dapat dirancang tampak atas, belakang depan dan samping, seperti pada Gambar 3 berikut ini.
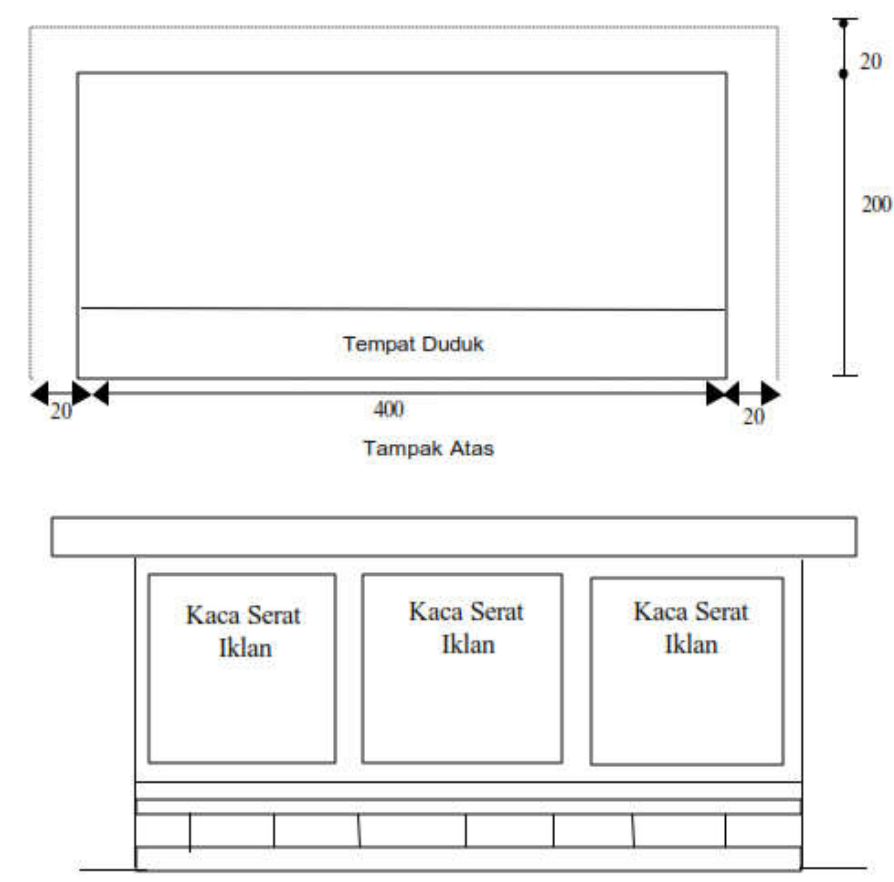

Tampak Belakang

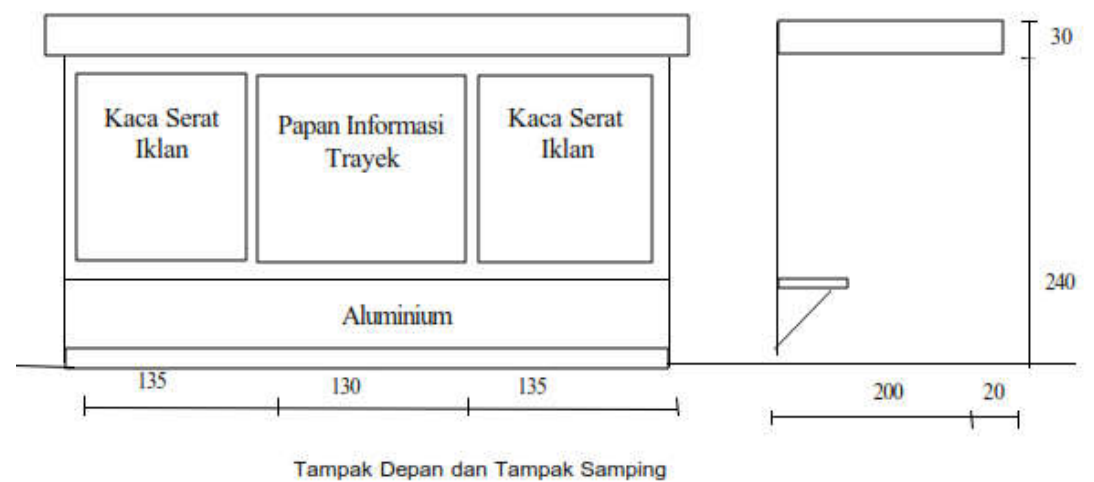

Gambar 3. Tampak Atas, Belakang dan Samping Halte Tipe 2 [5]

Halte Tipe 3 juga bisa dirancang tampak atas, belakang depan dan samping, seperti pedoman pada Gambar 4. 

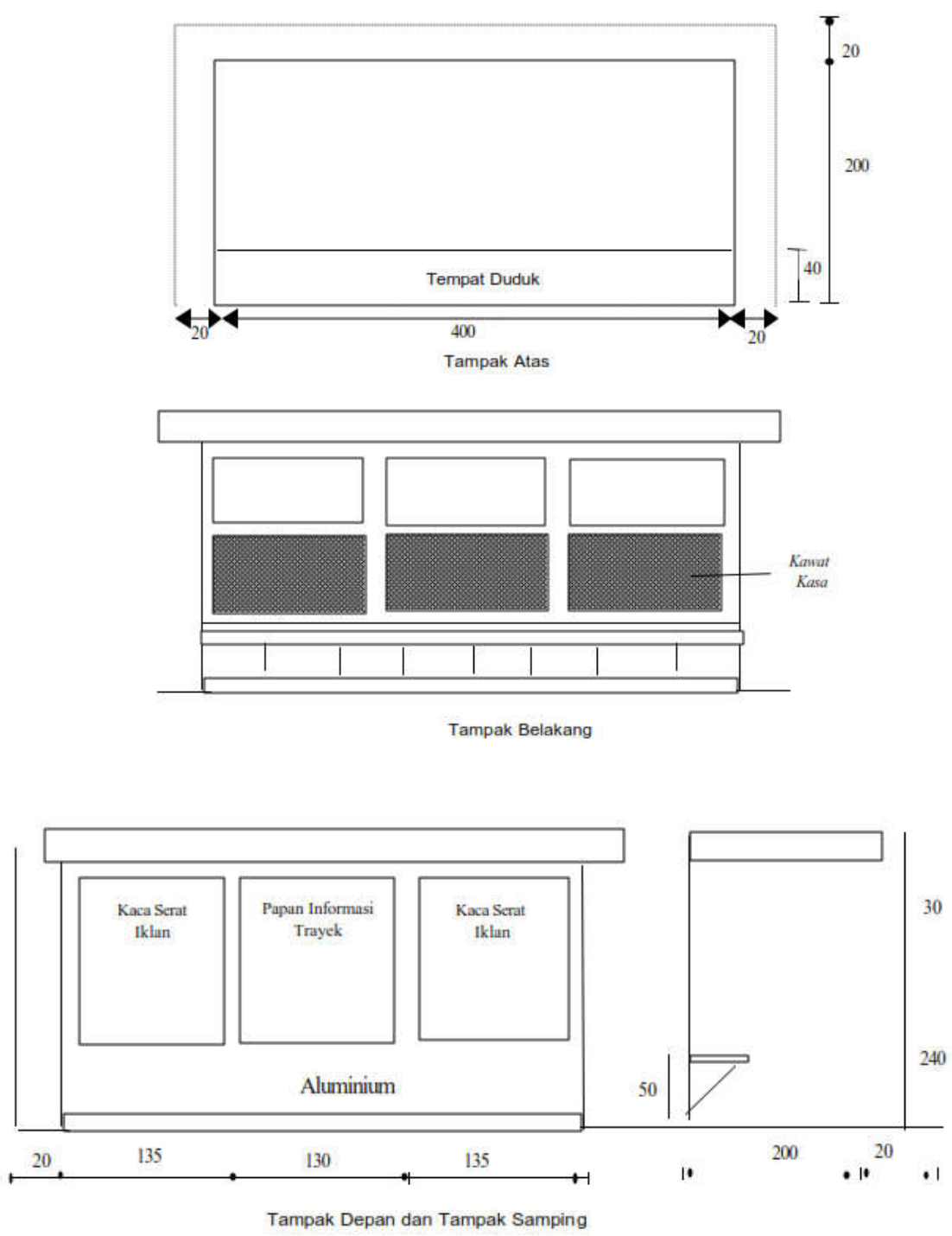

Gambar 4. Tampak Atas, Belakang dan Samping Halte Tipe 3 [5]

Secara umum, rancangan halte bus dapat dikreasikan berdasarkan tiga tipe halte tersebut di atas dengan memperhatikan masing-masing persyaratannya.

\section{METODE PENELITIAN}

Penelitian dimulai dengan melakukan survei dan observasi tentang masalah-masalah infrastruktur halte bus Trans Padang di sekitar kampus Universitas Negeri Padang. Langkah selanjutnya adalah mengkaji referensi yang terkait dengan permasalahan infrastruktur halte yang diteliti. Lokasi halte yang dipilih adalah halte di depan rektorat Universitas Negeri Padang. Pengambilan data dilakukan di lokasi penelitian melalui survei lapangan. Data yang diambil adalah jumlah pengguna bus yang menggunakan halte eksisting setiap hari selama 9 hari, daya tampung halte, bentuk, serta konstruksinya. Perhitungan rasio daya tampung halte dan kondisi struktur halte disesuaikan dengan Pedoman Teknis Perekayasaan Tempat Perhentian Kendaraan Penumpang Umum [5]. Dari hasil analisis data, dilakukan perancangan ulang halte. Hasil akhir penelitian berupa desain bentuk interior dan eksterior serta maket. Konsep perancangan yang digunakan adalah konsep ikonik dan kearifan lokal. Gambar dibuat dengan bantuan perangkat lunak AutoCAD dan SketchUp. 


\section{HASIL DAN PEMBAHASAN}

Dari hasil pengukuran halte eksisting, didapatkan data panjang ruangan halte 5,50 m, lebar ruangan halte $1,60 \mathrm{~m}$, tinggi lantai halte $0,70 \mathrm{~m}$ dari permukaan jalan, dan tinggi atap halte 3,00 $\mathrm{m}$ dari lantai halte. Luas ruangan halte adalah 8,80 m2. Analisis daya tampung dilakukan dengan berpedoman pada Standar Pelayanan Minimal Angkutan Massal Berbasis Jalan [6]. Berdasarkan pedoman tersebut, luas kebutuhan halte adalah sebagaimana yang tercantum pada Tabel 1 di bawah ini.

Tabel 1. Luas Kebutuhan Ruang [6]

\begin{tabular}{|c|l|l|}
\hline No & \multicolumn{1}{|c|}{ Uraian } & \multicolumn{1}{|c|}{ Volume } \\
\hline 1 & Luas kebutuhan pada jam puncak & 4 orang per m2 \\
\hline 2 & Luas kebutuhan pada jam non puncak & 2 orang per m2 \\
\hline 3 & Jarak bebas antar penumpang & $30 \mathrm{~cm}$ \\
\hline
\end{tabular}

Untuk analisis daya tampung, survei jumlah pengguna halte dilakukan selama 9 hari. Pada jam non puncak diperoleh pengguna halte maksimal sebesar 22 orang sehingga didapatkan luas kebutuhan halte sebagai berikut:

$$
\text { Luas kebutuhan ruang }=\frac{\text { jumlah pengguna maksimal }}{\text { jumlah kebutuhan ruang }}=\frac{22}{2}=11 \mathrm{~m} 2
$$

Jika dibandingkan dengan luas halte eksisting yaitu 8,80 $\mathrm{m} 2$, maka berdasarkan perhitungan tersebut luas ruang halte perlu ditambah menjadi $11 \mathrm{~m} 2$ sesuai dengan jumlah maksimal pengguna halte di jam non puncak. Desain halte sendiri disesuaikan dengan karakter bangunan di sekitar halte, terutama gedung rektorat Universitas Negeri Padang yang memiliki desain khas. Bangunan rektorat baru yang mulai digunakan pada tahun 2017 ini, pada saat ini menjadi salah satu bangunan ikonik di Kota Padang. Rancangan halte mengambil bentuk utama dan warna yang sama dengan bangunan rektorat. Desain halte berdasarkan karakter bangunan ikonik ini kemudian dipadukan dengan desain ukiran khas Minangkabau dan penggunaan warna marawa (bendera/panji) hitam, kuning dan merah yang melambangkan 3 wilayah adat (luhak) di Minangkabau. Hasil desain halte bus Trans Padang selengkapnya dapat dilihat pada Gambar 5 hingga Gambar 12 berikut ini.

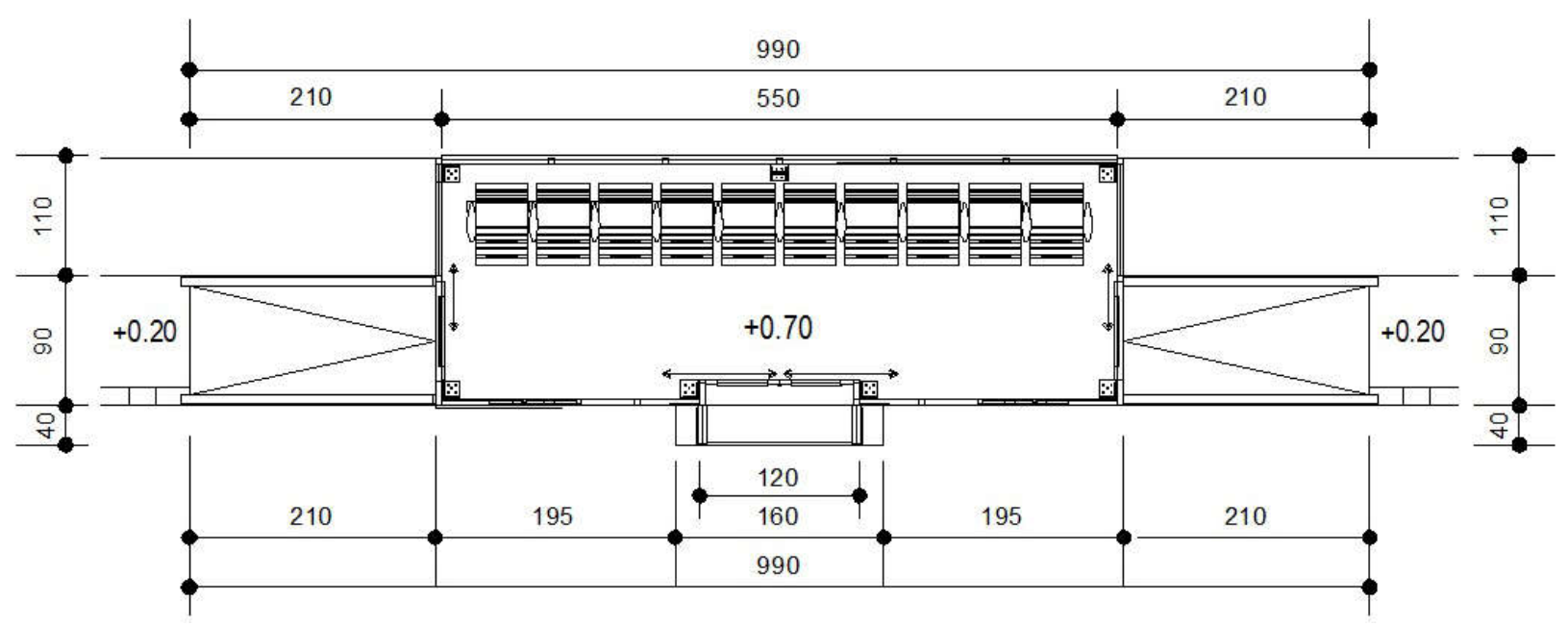

Gambar 5. Denah Halte Bus Hasil Rancangan 


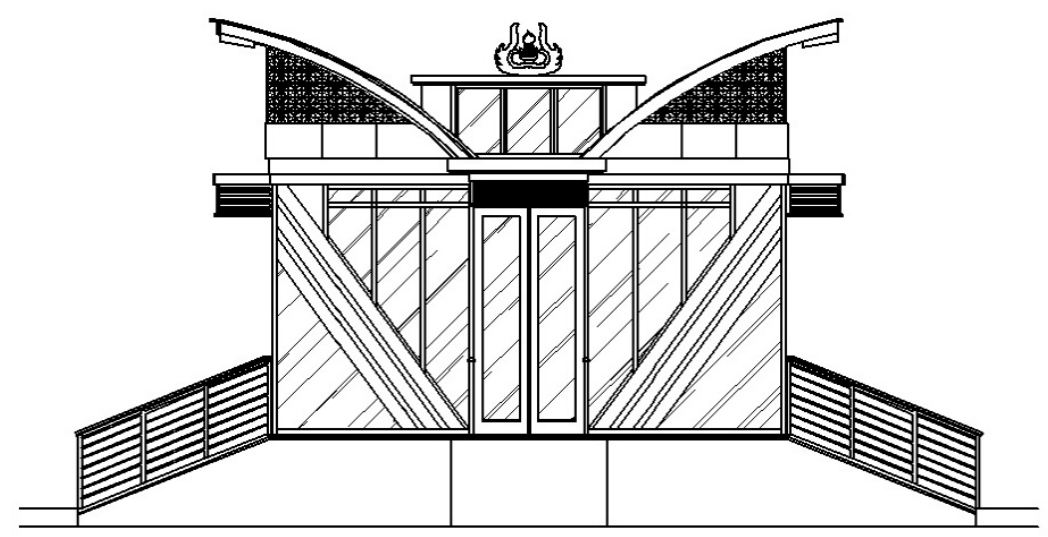

Gambar 6. Tampak Depan Halte Bus Hasil Rancangan

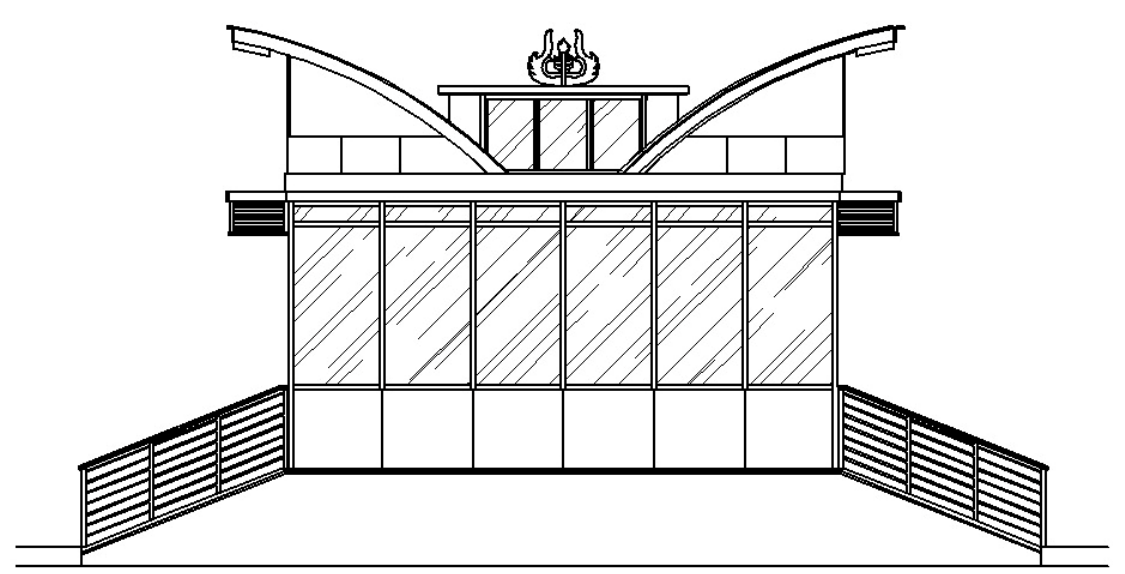

Gambar 7. Tampak Belakang Halte Bus Hasil Rancangan

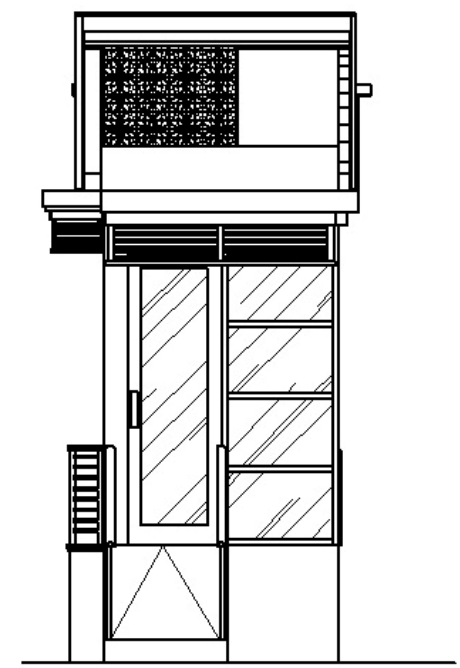

Tampak Kanan

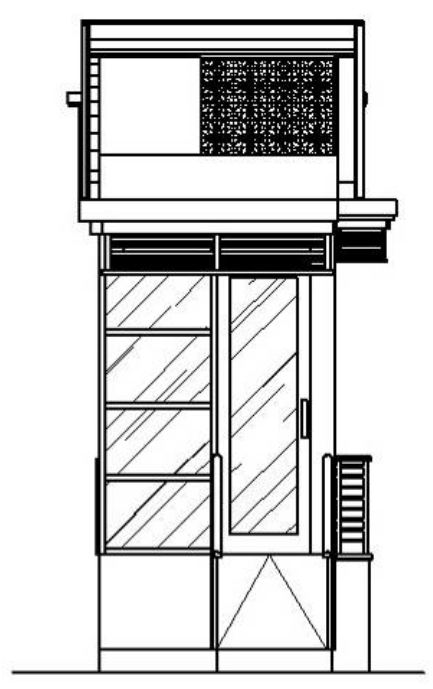

Tampak Kiri

Gambar 8. Tampak Kanan dan Tampak Kiri Halte Bus Hasil Rancangan 


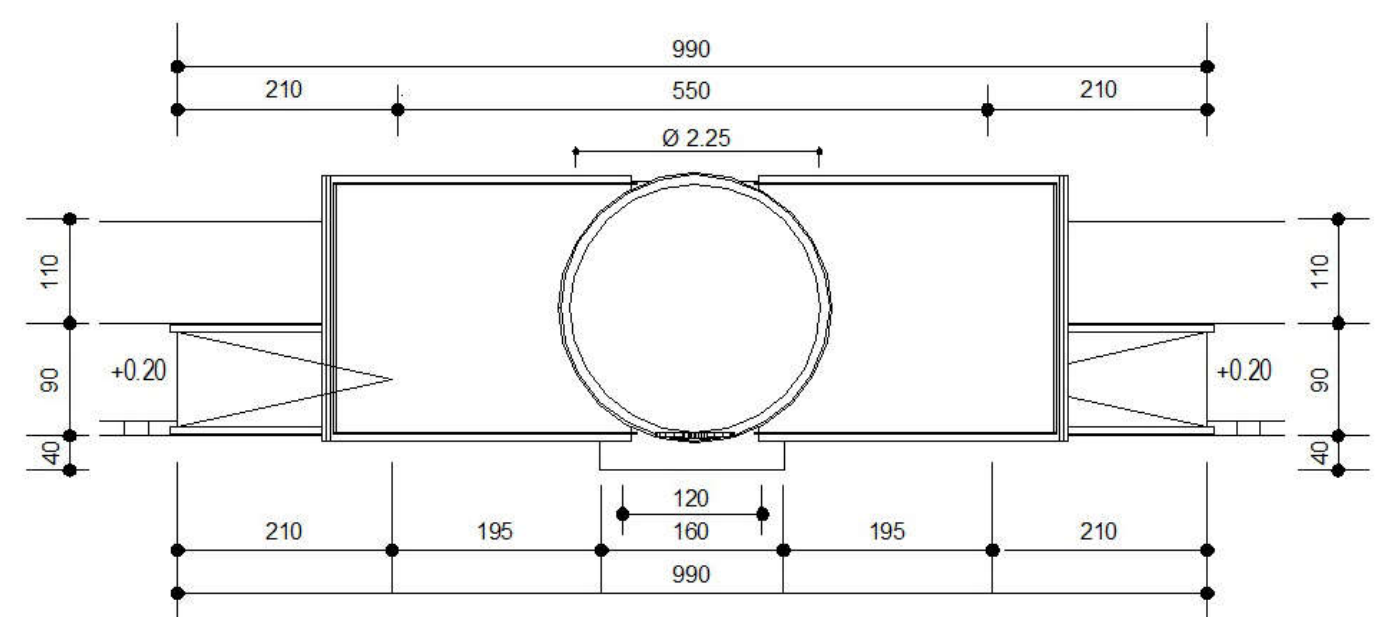

Gambar 9. Tampak Atas Halte Bus Hasil Rancangan

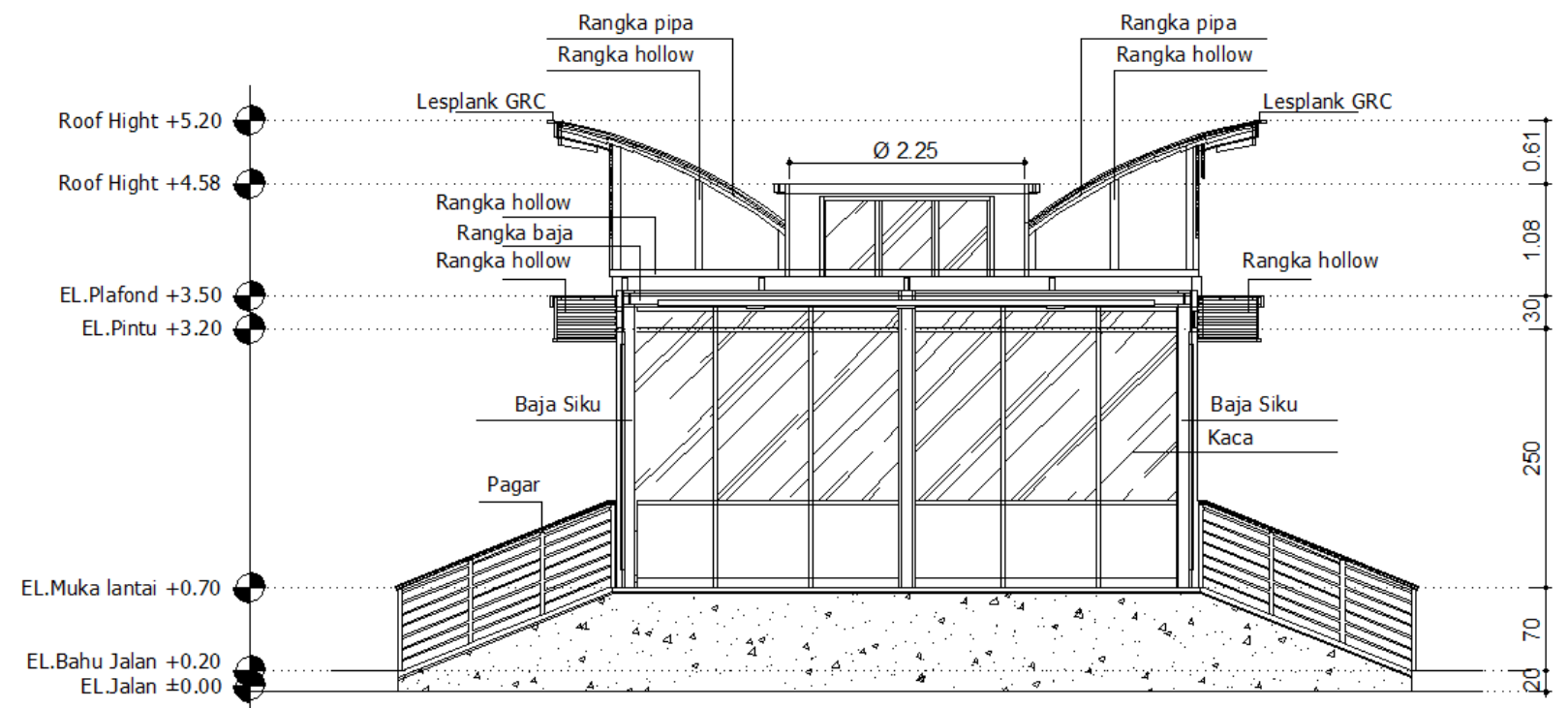

Gambar 10. Potongan A-A Halte Bus Hasil Rancangan

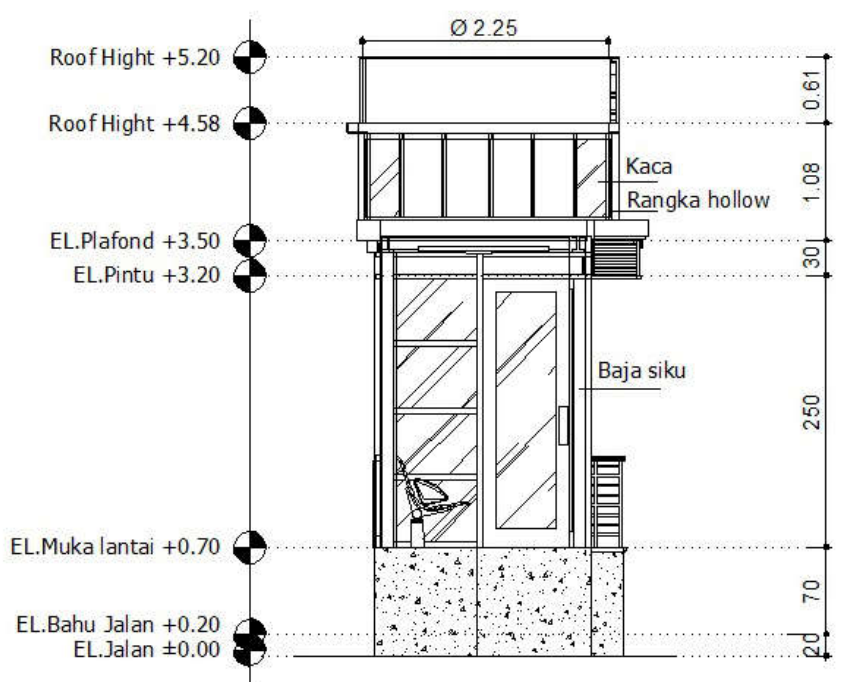

Gambar 11. Potongan B-B Halte Bus Hasil Rancangan 


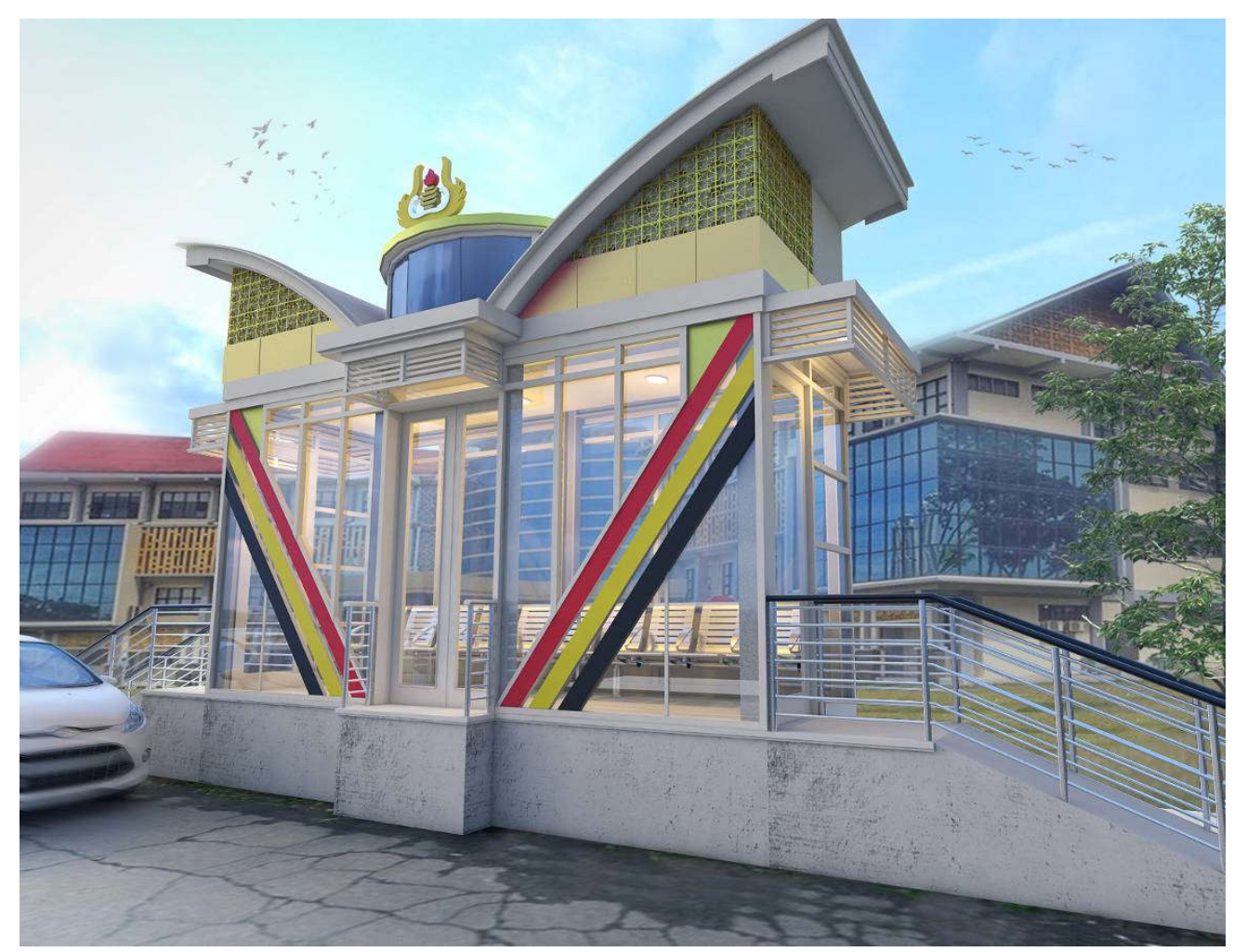

Gambar 12. Gambar 3D Halte Bus Hasil Rancangan

\section{SIMPULAN}

Luas kebutuhan riil ruang halte adalah $11 \mathrm{~m} 2$. Jika dibandingkan dengan luas halte eksisting yaitu 8,8 m2, maka luas ruang halte tersebut tidak memenuhi syarat. Telah dibuat gambar rancangan yang memenuhi syarat sesuai dengan luas kebutuhan ruang halte yang sebenarnya. Desain yang dibuat mengusung konsep iconic dan kearifan lokal dengan mengikuti karakter desain bangunan rektorat UNP baru. Desain halte ini juga telah disesuaikan dengan Pedoman Teknis Perekayasaan Tempat Perhentian Kendaraan Penumpang Umum.

\section{DAFTAR RUJUKAN}

[1] S. I. Novita. "Perbaikan Rancangan Fasilitas Halte Bus Trans Padang dengan Prinsip Ergonomi dan Analisis Rate of Return." Tugas Akhir. Universitas Andalas, Padang. 2017.

[2] U. Pawitro. “Pemahaman Keterkaitan 'Teori Arsitektur' - Kegiatan 'Perancangan' dan 'Kritik Karya' dalam Arsitektur.” Jurnal Itenas Rekayasa, Vol. 13 No. 4, pp 176-183, Desember 2009.

[3] A. Ibeas et. al., "Optimizing bus stop spacing in urban areas", Transportation Research Part E, Vol. 46 No. 3, pp 446-458, May 2010.

[4] B. Adhvaryu, "Design of bus station: a case study in Brighton", Traffic Engineering and Control, Vol. 47 No. 5, pp 182-187, May 2006.

[5] Keputusan Dirjen Perhubungan Darat No. 271/HK.105/DRJD/96, "Pedoman Teknis Perekayasaan Tempat Perhentian Kendaraan Umum", 1996

[6] Peraturan Menteri Perhubungan Republik Indonesia Nomor: PM. 10 Tahun 2012. "Standar Pelayanan Minimal Angkutan Massal Berbasis Jalan", 2012. 


\section{Biodata Penulis}

Risma Apdeni, lahir di Pasaman, 7 April 1971. Gelar Sarjana Teknik dan Magister Teknik diraih dari Universitas Gadjah Mada. Sejak tahun 1999 menjadi dosen di Jurusan Teknik Sipil Universitas Negeri Padang.

Fitra Rifwan, lahir di Lubuk Basung, 12 Juni 1986. Pendidikan sarjana diselesaikan di Jurusan Teknik Sipil Universitas Negeri Padang dan gelar Magister Teknik diraih dari Universitas Andalas. Menjadi dosen di Jurusan Teknik Sipil Universitas Negeri Padang sejak tahun 2012. 